\title{
Sustainable management and its impact on the development of the shrimp farming sector in the municipality of Guasave, Sinaloa, México.
}

\author{
Beltrán-Lugo Lizbeth ${ }^{1}$ \\ Faculty of Economic and Administrative Sciences, Autonomous University of \\ Sinaloa, Juan de Dios Bátiz Boulevard, San Joachin, Guasave, Sinaloa, México, CP. \\ 81101.

\section{Izaguirre-Díaz de León Fridzia²} \\ Universidad Autónoma de Occidente. Av. Universidad s/n, Frac. Villa Universidad, Guasave, \\ Sinaloa, México, CP.81044. \\ Corresponding author: fridziaizaguirrediazdeleon@gmail.com
}

\section{López-Nevárez Virginia ${ }^{3}$}

Universidad Autónoma de Occidente. Carretera Internacional México $15 \mathrm{~km} 5$ esq. Blvd. Macario Gaxiola, Ahome, Sinaloa, México, CP.81200.

\section{Portillo-Molina Raul ${ }^{4}$}

Universidad Autónoma de Occidente. Av. Universidad s/n, Frac. Villa Universidad, Guasave, Sinaloa, México, CP.81044.

\section{Cordero-Ramírez Jesús Damián 5}

Universidad Autónoma de Occidente. Av. Universidad s/n, Frac. Villa Universidad, Guasave, Sinaloa, México, CP.81044.

\section{Peinado-Guevara Victor Manuel ${ }^{6}$}

Faculty of Economic and Administrative Sciences, Autonomous University of Sinaloa, Juan de Dios Bátiz Boulevard, San Joachin, Guasave, Sinaloa, México, CP. 81101.

\begin{abstract}
The operative context in which companies are currently developing has changed, moving towards a sustainable environment; innovating and migrating towards a business model focused on sustainable management leads to a better economic, environmental and social performance of the organization. The objective of this research is to diagnose the administrative practices carried out in the shrimp farming sector of the municipality of Guasave, Sinaloa, in relation to sustainable management. The research is based on a qualitative approach, through a multi-case study strategy applicable to 6 companies located in the study area, with an exploratory, explanatory, documentary and non-experimental scope. Categories are defined according to the three main themes of the research: management factors in the organization, commercial management and sustainability management. The results show that there are notions of the importance of the management of factors aimed at sustainability, however, there is still a
\end{abstract}


vague ecological awareness in the sector. It is concluded that it is essential for the shrimp farming sector to develop strategies and guidelines aimed at achieving sustainable management, which will allow meeting the requirements of national and international organizations and the creation of economic and non-economic value.

Keywords. Sustainability, commercial management, organizational management.

\section{Introduction}

The vision under which business decisions are directed is changing towards a new sustainable perspective; environmental care and the way of doing business has evolved, since, social demands require companies to avoid development at the cost of damage to the environment [1]. Therefore, in the recent years, companies have faced increasing pressure for greater social and environmental responsibility, accountability and sustainability [2].

A fundamental issue when addressing the topic of sustainable management, are ethical values and decision making in organizations; according to [3] great ethical ideas can be transformed into specific actions and decisions and emphasizes the importance and desirability of developing ethics and accountability in business management. This will prevent cases of corruption with regrettable outcomes, and will help companies and the business world to work towards building a fairer society.

[4] points out that sustainable management has helped organizations to increase their interest in implementing sustainable solutions. Sustainable management models, incorporate proactive stakeholder management, encourage the creation of economic and non-economic value and help to maintain a long-term perspective [5].

The knowledge, skills and experiences regarding the environmental issue of employees, as well as the promotion of a green culture and green innovations, are fundamental to consolidate strategies aimed at sustainable management [6]. Therefore, the human factor is essential when talking about sustainability [7]. And [3] argue that the appropriate model for management starts from ethical foundations in the processes as the basic pillars of management.

The globalization of markets, makes companies seek strategies to be more competitive, so, redirect the objectives of organizations towards a value rationality motivated by the awareness of a more social responsibility and oriented to the preservation and care of natural resources. It is essential for companies to evolve and adapt to these changes, for which it is necessary to establish strategies aimed at facing these challenges [1].

In this context, the aquaculture sector chosen for the study is described, more specifically, the shrimp farming activity, deliberately selected for its development over the last thirty years and its economic, social and environmental importance in the region.

Aquaculture is an activity that stands out for its capacity to generate food and economic income for hundreds of millions of people around the world. Thanks to an intense growth of this important activity, it is by which, currently, provides half of all fish destined for human consumption, and, to a slight improvement in the situation of some fish stocks, as a result of better fisheries management [8].

Global fish production reached an output approaching 171 million tons in 2016, of which, aquaculture accounted for $47 \%$ of the total and 53\% if non-food uses are excluded [9]. Data from [10] indicates that aquaculture production in Mexico generated a total of 404 thousand tons of fish and shellfish farmed in coastal maritime areas, inland waters and ponds in Mexico throughout 2017, which represented an economic spillover of 17,813 million pesos, with a positive effect on the economy in rural communities in the national territory. 
The production of farmed shrimp has generated an exponential growth in aquaculture, due to the importance it represents for the population's food security and for national economic development. Likewise, it is worth highlighting that Sinaloa is among the five entities with the highest shrimp fishery production, which concentrate $92.9 \%$ of the country's total production [10]. Among the main entities involved in the production of farmed shrimp in the state of Sinaloa are: Ahome, Guasave, Angostura, Navolato, Eldorado, Cospita, Elota, Mazatlán-San Ignacio, El Rosario and Escuinapa (Table 1). Regarding the cultivation cycles from 2010 to 2019, the behavior of farmed shrimp production in Sinaloa has maintained a sustained growth (Figure 1), which indicates the intense growth of the activity in the state.

Table 1. Main producing entities in the state of Sinaloa, cultivation cycles 2010-2019

\begin{tabular}{lcccccccccc}
\hline & \multicolumn{1}{c}{ Shrimp production (tons)(Kg/ha) } & & & & \\
Local Aquatic Health & 2010 & 2011 & 2012 & 2013 & 2014 & 2015 & 2016 & 2017 & 2018 & 2019 \\
Board & & & & & & & & & & \\
\hline Ahome & 1,027 & 1,612 & 1,169 & 1,169 & 731 & 1,278 & 1,611 & 948 & 1,701 & 1,655 \\
Guasave North & 868 & 959 & 670 & 670 & 531 & 955 & 728 & 900 & 1,002 & 1,065 \\
Guasave South & 959 & 1,063 & 690 & 690 & 518 & 926 & 1,005 & 1,113 & 1,144 & 1,188 \\
Angostura & 902 & 984 & 570 & 570 & 550 & 909 & 766 & 985 & 759 & 879 \\
Navolato North & 530 & 788 & 723 & 723 & 429 & 501 & 460 & 570 & 681 & 742 \\
Navolato South & 761 & 1,108 & 783 & 783 & 243 & 679 & 466 & 546 & 804 & 898 \\
Eldorado & 642 & 865 & 694 & 694 & 266 & 601 & 437 & 609 & 636 & 697 \\
Cospita & 694 & 1,138 & 680 & 680 & 126 & 391 & 825 & 423 & 656 & 630 \\
Elota & 456 & 759 & 440 & 440 & 219 & 191 & 356 & 413 & 454 & 521 \\
Mazatlán-San Ignacio & 663 & 1,180 & 810 & 810 & 488 & 486 & 1,167 & 799 & 648 & 849 \\
Rosario & 1,046 & 1,059 & 1,098 & 1,098 & 2,622 & 1,158 & 2,652 & 677 & 1,420 & 1,415 \\
Escuinapa & 899 & 1,983 & 1,617 & 1,617 & 1,463 & 1,106 & 1,248 & 2,647 & 661 & 702 \\
Totals & 811 & 1,109 & 805 & 288 & 456 & 765 & 977 & 886 & 881 & 937
\end{tabular}




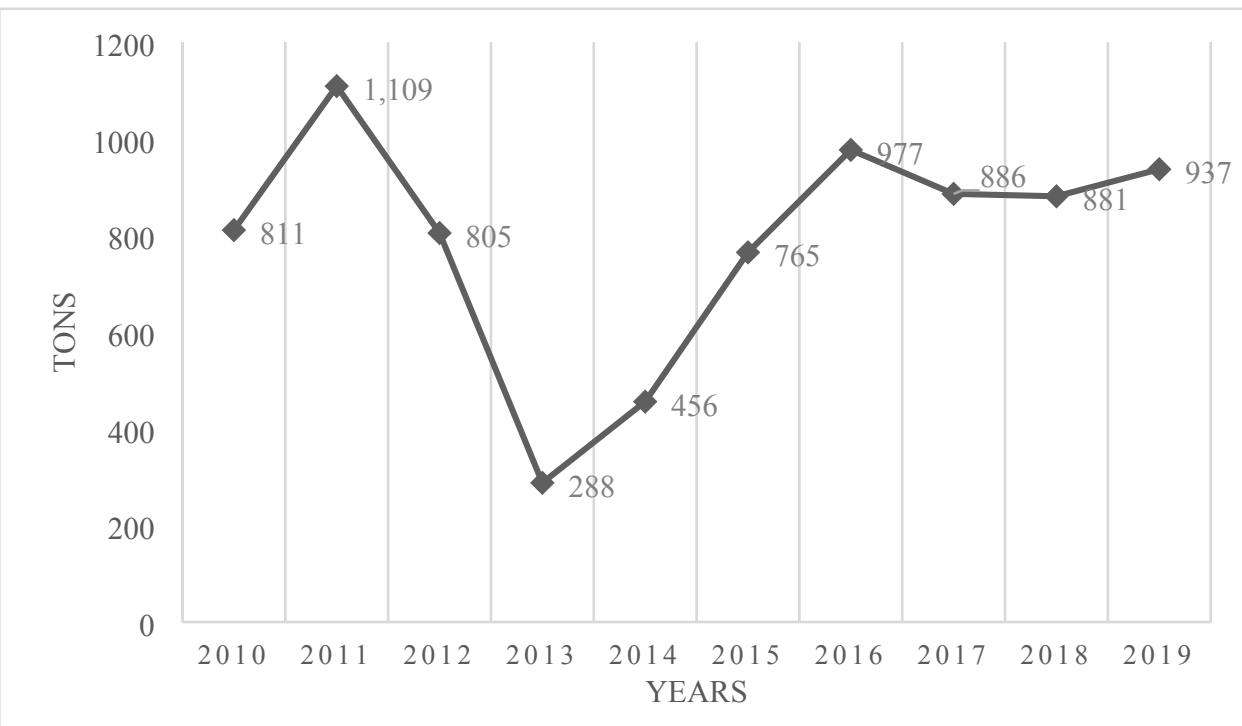

Figure 1. Behavior of farmed shrimp production in Sinaloa from 2010 to 2019. Source: own elaboration with data from CESASIN, (2020).

Based on data from [11] Sinaloa ranked first in terms of shrimp production during the 20192020 fishing season, which ended in March, producing 19,551 tons, followed by Sonora with 12,579 tons, and Nayarit with 2,844 tons. In northwestern Mexico, shrimp farming is considered one of the most important activities; however, it faces several challenges, among which are the large economic losses related to diseases during its cultivation. At the same time, it is causing great damage to the environment as a result of the intensive intervention caused by the aquaculture practices involved in the activity [12].

However, beyond the economic and social benefits, this sector has been severely criticized for its unsustainable production systems [13] and for its negative impact on the environment [12], such as land use change, mangrove deforestation and different types of pollution [14]. This has motivated that, stakeholders involved in the productive processes are increasingly aware that aquaculture carries risks [15] and that the seafood they consume may originate from unsustainable sources. Hence the importance of the study, since it is of interest, to know the dynamics of the productive processes seen from a sustainable approach in an area that stands out for its high productive capacity of the sector. It should be noted that aquaculture in Guasave is mainly carried out in ponds (farms) near the coast.

This technique has a greater impact on the environment than aquaculture using floating cages in the marine environment because it changes land use, antibiotics are used for disease control and the effluents cause contamination in the receiving water bodies [16].

The above reveals the need for a management model that truly identifies which sustainability factors have an impact on each dimension of sustainable development, in order to promote new strategies, especially in the environmental dimension, without neglecting the social and economic dimensions, in order to make ecological development profitable and thus be able to respond to regulatory pressures, based on managerial practice, from strategic management to policy formulation.

We chose to study the shrimp farming sector in the region of Guasave, Sinaloa, Mexico, because of the importance of this activity in satisfying the seafood needs of the population, but also because of the possibility of impacting the social development of the regions where the farms are located and the negative impact they can have on the environment, making it essential to pay attention to local 
and global problems. It is also important to note that there is very little research oriented to sustainability management in the study area. It should also be noted that the municipality of Guasave is the leader, occupying second place in the state, in terms of shrimp production and the number of hectares of water mirror planted and harvested.

Likewise, this research contributes to the fulfillment of the Sustainable Development Goal (SDG) 12 responsible production and consumption according to the United Nations (UN). The economic and social progress that has been achieved in the last century has been reflected in environmental damage that is endangering the very systems on which our future development depends. Sustainable consumption and production seeks to make rational and responsible use of natural resources, decoupling economic growth from environmental degradation, increasing resource efficiency and promoting sustainable lifestyles [17].

According to the United Nations Development Program (UNDP), the efficient management of shared natural resources and the way in which toxic waste is disposed of is of great importance to achieve this goal. Likewise, it is of great relevance to create awareness in the business sector and society in general and to urge recycling and waste reduction, and to support countries in developing and moving towards sustainable consumption styles by 2030 .

According [18] world aquaculture, and particularly shrimp farming, is and will continue to be an industry of great importance due to its sustained growth compared to other agro industrial food production activities, and Mexico is no exception to this situation, since a large-scale growth in aquaculture activity, particularly in shrimp farming, is expected in the coming years.

\subsection{Theoretical and technical considerations of the investigation}

Mexico, like other countries in Southeast Asia and part of Latin America, has experienced an expansion in aquaculture activities. Among the causes that help explain the high growth rates of shrimp farming are high market demand (especially from developed countries), technological progress and the reduction of production volumes from wild stocks [19].

Regarding the social factor, [20] points out that aquaculture has undergone an exponential change in the international context in the last three decades, which has generated economic and social growth for the sectors dedicated to this activity, helping, in an important way, to generate employment and in the production of high-quality protein-rich food for human consumption. Globally it plays an important role, focusing its objectives on efforts to eradicate hunger, providing food and, in general, improving people's health and quality of life, which has allowed, that social perception and trust of aquaculture are essential conditions that support the granting of a social license to operate [21].

According [22] certification schemes in the aquaculture sector that address issues concerning social sustainability are mainly focused on workers' rights or directly linked to environmental sustainability and the required actions rarely go beyond existing legal requirements. Essentially, aquaculture sustainability certification schemes have not yet seized the opportunity to shape our understanding of what social sustainability means, or how it is practiced.

With the purpose of promoting long-term sustainable fisheries and aquaculture, in 1995 the Food and Agriculture Organization of the United Nations (FAO) conference approved the Code of Conduct for Responsible Fisheries and Aquaculture, establishing the basis for international principles and standards of behavior for responsible practices, aimed at ensuring the conservation, management and effective development of living aquatic resources, with respect for the ecosystem and biodiversity, recognizing the nutritional, economic, social, environmental and cultural importance [20].

It has been a great challenge to estimate the magnitude of the environmental impact of aquaculture production, despite being a rapidly expanding activity, it should be noted that sustainability perspectives have been a concern since the early 1990s [23]. To minimize the damage caused by 
aquaculture, [24] proposes a series of guidelines aimed at preventing and reducing damage to the environment, such as controlling certain activities in areas where aquaculture production is carried out, establishing good practice guidelines regarding the use of inputs and raw materials, regulating waste, and constantly monitoring if any ecological changes occur.

[25] Agree that environmentally concerned production implies substantial changes in food decisions, which are conditioned by economic and quality factors, unfortunately, the complex integration of all these factors, which sometimes oppose each other, limits the ability of aquaculture producers to adapt their production strategy to cleaner production systems.

Therefore, it can be recapitulated that there is still a long way to go for shrimp farming to become a sustainable activity; however, it can become so if it is properly managed, taking into account economic, ecological, financial and social aspects, which will promote shrimp farming as a sustainable industry [18].

\subsubsection{Stakeholders and business management}

It was Edward Freeman who defined the concept of stakeholders, which was born in the 70's, showing that its genesis is linked to its strategic use. He defines stakeholders as "any group or individual that can affect or be affected by the achievement of a corporation's objectives" [26, p. 229].

According [27] downstream stakeholder engagement can help companies create value for the market and increase their new product development financial performance. It is well known that stakeholder involvement leads to better decision making. However, it is essential for decision makers to identify and involve the most suitable stakeholders according to the organization's focus [28].

With regard to business management aimed at achieving the organization's objectives, the interaction of the dimensions of human development, such as working conditions and productivity [29], are fundamental elements of great importance in sustainable management.

Likewise, with regard to business management, the attention and interest shown by companies to groups, organizations and individuals, which for a long time were ignored by those same companies, has increased exponentially. It has been observed that in some companies there is a decision to satisfy the expectations, desires, interests and demands of their stakeholders [30].

Nowadays, companies have seen the need to develop and adopt a large number of processes in order to meet the needs and expectations of stakeholders in their performance, giving great importance to the needs of customers, including the need to perform different quality, environmental, occupational health and safety and other legal and regulatory requirements, which is of great relevance to generate productivity, efficiency and effectiveness rates, improve their competitiveness and profitability, as part of meeting the expectations of today's globalized markets [31]. In this way, business management contemplates all the activities that can have a positive impact on the organization.

\subsubsection{Sustainability management and business management}

Sustainability (or sustainability, according to the Spanish linguistic form agreed upon by the United Nations), is the general paradigm of the United Nations. The concept of sustainable development was described by the 1987 Bruntland Commission Report as "development that meets the needs of the present without compromising the ability of future generations to meet their own needs" [32]. Today, thirty-four years after the appearance of the 1987 United Nations Report, called the Brundtland Report, also known as Our Common Future, sustainability is one of the most relevant topics in terms of environmental, social and economic care.

It is also one of the paradigms that characterize the 21 st century, and therefore it is important that it forms an integral part of the management of organizations. It should be noted that for an organization to be considered sustainable, it is necessary to have a responsible culture, which implies a 
deep ethical reflection aimed at creating awareness, sensitization and training in order to achieve consistent and lasting behaviors [33].

Market demands and new trends require the implementation of another component as part of new business and innovation models: sustainable development. However, even today, many companies have difficulties in recognizing the advantages of opting for this type of management aimed at sustainability, so it is necessary to provide guidance on how to evaluate themselves in terms of sustainability and how to generate strategies to achieve their goals and to be aware that it is a process, therefore it takes time, taking into account that it is necessary to change ways of thinking and ingrained beliefs, but adopting this type of management will help to deal with economic, social and environmental challenges that are envisioned in the SDGs [34].

On the other hand, business management and business growth are two variables that must be closely related to achieve the success of organizations, on this many theorists have generated their contributions.

One of the most important functions in any type of company, regardless of its nature or size, is commercial management, whose mission is to be responsible for the opening of the organization to the outside world, among its main activities are: customer satisfaction, market share, increasing sales, dosing marketing activities, training human resources, improving administrative processes, guiding in this assembly of work to achieve profitability, which leads to the growth of the company [35]. Nowadays, customers require products and services that fully satisfy their needs, and there are multiple tools in commercial management to evaluate the attractiveness of the store activity. Therefore, this important element is an important part of the management system in organizations, which makes it possible to know the market, the competition and adapt to the new and changing conditions of the environment, supporting decision-making based on the opinion of real and/or potential customers as an indispensable requirement for organizational success [36].

The shrimp farming sector in the municipality of Guasave, which is the subject of study of this research, cannot be exempt from these dynamics, typical of modern management.

\section{Research methods and techniques}

The methodological proposal to address the problem posed in the body of this research is based on a qualitative approach, using a multi-case study strategy, applicable to shrimp farming companies located in the municipality of Guasave, Sinaloa [37].

\subsection{Description of the study area}

The study area includes the coastal zone of the municipality of Guasave, Sinaloa Mexico, where more than 152 shrimp farms have been developed [38]. The most used production systems are: extensive, semi-intensive and intensive. And these types of production use a greater amount of inputs and raw materials, which translates into greater environmental damage. 


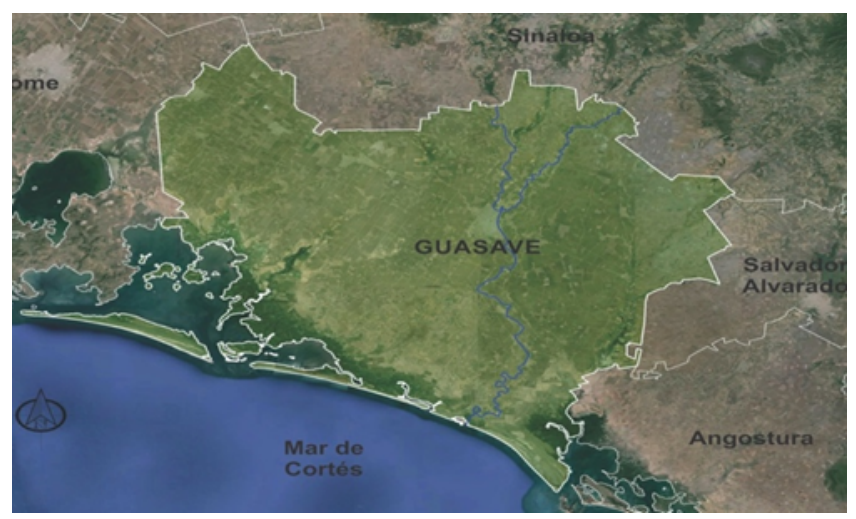

Figure 2: Location of Guasave in the state of Sinaloa. Source: Guasave.gob.mx.

The municipality of Guasave was chosen as the study area because it is one of the leading municipalities in the production of farmed shrimp, with the second largest land area planted, harvested and in terms of production (Table 2).

Table 2. Sowings and harvests in the municipality of Guasave concentrated 2020.

\begin{tabular}{ccccccc}
\hline & \multicolumn{2}{c}{ Sowing advances } & \multicolumn{4}{c}{ production data } \\
\hline JLSA & $\begin{array}{c}\text { Farming } \\
\text { company }\end{array}$ & $\begin{array}{c}\text { Planted } \\
\text { Área } \\
\text { (Has) }\end{array}$ & $\begin{array}{c}\text { Harvested } \\
\text { companies }\end{array}$ & $\begin{array}{c}\text { Harvested } \\
\text { Area }\end{array}$ & $\begin{array}{c}\text { Total } \\
\text { production } \\
\text { (Ton) }\end{array}$ & $\begin{array}{c}\text { Profit. } \\
\text { Kg./Ha. }\end{array}$ \\
$\begin{array}{c}\text { Guasave } \\
\text { North }\end{array}$ & 90 & $7,182.32$ & 70 & $5,429.56$ & $5,224.70$ & 962.30 \\
$\begin{array}{c}\text { Guasave } \\
\text { Suoth }\end{array}$ & 62 & $4,277.24$ & 32 & $1,990.86$ & $2,234.00$ & $1,122.10$
\end{tabular}

Based on the analysis of the different types of research, it was determined that the scope of this study will be exploratory, explanatory, documentary and non-experimental, since there are not many studies focused on the study of sustainable management in the shrimp farming sector, so a diagnosis was made of the management practices carried out in the shrimp farming sector in the municipality of Guasave, Sinaloa, in relation to sustainable management [39].

This study was framed in a field research, since the data were extracted directly from reality, through the use of semi-structured interviews directed to managers of shrimp farms in the municipality of Guasave, Sinaloa and to the president of CESASIN. On the other hand, this research is supported by documentary sources from which the theoretical foundations that support the research are built [40].

The sampling was defined randomly and by convenience through the multi-case strategy, taking as reference, those companies that maintain a production capacity of more than 100 hectares of water mirror and that the administrators or owners are willing to participate in the research process (Yin, 2003). In this section, cases have been selected according to the directory of active shrimp companies registered in the State Committee of Aquaculture Health of Sinaloa (CESASIN), which gives a total of 152 production units in the municipality of Guasave, Sinaloa.

According to the interview conducted on October 9, 2020 with the president of CESASIN, the following criteria were considered for the selection of the six case study companies: a) more than ten years in the market, b) greater territorial extension and production in the shrimp farming activity, c) that have recognition and certifications in terms of productive and environmental work (Table 3 ). 
Table 3. Case study companies

\begin{tabular}{lll}
\hline Companies & Information \\
\hline Case 1
\end{tabular}

Case 1

Planted area (Has)

240 Has.

Type of market

National and export

Number of administrative workers

7

Years in the market

10 years

Case 2

Planted area (Has)

175.3 Has.

Type of market

National

Number of administrative workers

5

Years in the market

15 years

Case 3

Planted area (Has)

172 Has.

Type of market

National and export

Number of administrative workers

6

Years in the market

22 years

Case 4

Planted area (Has)

110 Has.

Type of market

National

Number of administrative workers

5

Years in the market

11 years

Case 5

Planted area (Has)

160 Has.

Type of market

National

Number of administrative workers

6

Years in the market

21 yeras

Case 6

Planted area (Has)

192 Has.

Type of market

National

Number of administrative workers

7

Years in the market

50 years

Each shrimp farm was visited once a week, and data were obtained through various sources such as observation and semi-structured interviews [40]. The categories studied were: 
management factors in the organization, commercial management and sustainability management (Table 4).

Table 4. Research categories

\begin{tabular}{ll}
\hline & \multicolumn{1}{c}{ Research categories } \\
\hline Category 1 & Management factors in the organization \\
Category 2 & Business management \\
Category 3 & Sustainability management
\end{tabular}

\section{Results and discussion}

The following information shows the results of the semi-structured interviews conducted with managers and owners in the field work carried out in the selected companies belonging to the shrimp farming sector in the municipality of Guasave, Sinaloa.

Currently, there has been a growing concern in companies to do business in a more humane and ethical manner, either due to the requirements of international organizations, national standards, practices followed in the business environment or as a way to generate competitive advantage [3], so the role of sustainable management as a generator of long-term progress is fundamental. Likewise, it has been observed that sustainable management models are considered as a source of competitive advantage that generates additional opportunities for value creation $[41,5]$.

Therefore, it is essential to integrate social and environmental concerns to work constantly in the generation of strategies, management models and risk analysis of any organization if it wishes to remain in today's competitive markets [42].

And aquaculture, more specifically the shrimp farming sector, is no exception to this problem; likewise, it is an industry that has achieved great development in the last thirty years and has great economic, social and environmental relevance [9].

\subsection{Category: Management factors in the organization}

It is observed that, for most of the companies studied, the economic, social and environmental factor are important, due to the fact that they go hand in hand, it is part of a gear. From which it is possible to take up the contribution of [22], that social perception and trust in aquaculture are essential conditions that support the granting of a social license to operate. However, nowadays, management decisions have become increasingly complex, taking into account issues such as environmental sustainability and product quality [27].

For the companies analyzed, the environmental factor is considered as an important element to manage in their organization, because they consider that, if there is a good relationship with the environment, this allows the activity to be sustainable. [43] state that companies that offer an environmental commitment in their production processes are less likely to exit the industry, and that there is a positive effect of economic profitability and long-term solvency on survival. This position is in line with stakeholder theory, which indicates that the fact that organizations can survive depends to a large extent on stakeholders as the main consumers of the goods and services offered by companies.

For [44] shifting business ethics to stakeholder responsibility management is not only consistent with the understanding of social systems as complex and self-constituted, but also with the understanding of companies as systems of complex interactions. Therefore, it is essential for companies to have good relations with the different stakeholders and to commit themselves to sustainable 
development and all that it comprises, with the improvement of society's life and consolidation of the economy, resulting in a competitive, stable and adequate environment for the achievement of the diverse interests of stakeholders and business goals [45].

\subsection{Category: Commercial management}

Regarding the commercialization of the product abroad, the minority of the case study companies said that they export their products abroad, mainly to the United States, Japan and soon to China. The rest of the companies studied said that their market is mainly regional and national. Regarding the issue of required certifications related to sustainability for export, the two case study companies said that the standards required of them are safety standards, those requested by the National Health, Safety and Quality Service (SENASICA) and that production does not affect the Gulf of California for the vaquita porpoise.

[22] state that certification schemes in the aquaculture sector, while addressing social sustainability issues, focus primarily on workers' rights or link directly to environmental sustainability, and the actions required rarely go beyond existing legal requirements. Essentially, aquaculture sustainability certification schemes have not yet seized the opportunity to shape our understanding of what social sustainability means, or how it is practiced. As far as can be seen, there are actions aimed at pursuing social sustainability, however, there is still much work to be done in this regard

On the other hand, [46] argue that estimating the magnitude and sustainability of environmental impacts represents a great challenge in the aquaculture sector. The lack of quantifiable data on sustainability performance is limiting the industry's ability to demonstrate the potential benefits of this important activity, as it plays an essential role in the future supply of seafood products. So they relied on global certification and qualification schemes to provide new tools to define and advance the quantification of sustainable aquaculture. This shows that there is still a lot of work to be done in the continued development of sustainable aquaculture.

\subsection{Category: Sustainability management}

[1] mention that, in the shrimp farming sector in the state of Sinaloa, there is little participation in environmental care, although it cannot be said that there are no actions aimed at this purpose, however, it is possible to point out that it is insufficient, mainly because if these actions are related to organizational factors such as culture, structure, management, and technological innovation, the scarce ecological awareness that still exists in this sector can be observed.

Most of the case study companies said they were familiar with the concept of sustainability, and when questioned about their position on sustainability from a competitive point of view, they said that it generates economic and social value and reduces costs; it also contributes innovation and positioning of the company, and that it is very important to be sustainable over time; in addition, they said that the idea is to be sustainable in the sense of producing increasingly organic shrimp. Only one of the case study companies said that it does not know the term sustainability and does not consider it important from a competitive point of view. In addition, all six companies said that they do not have a sustainable management model.

In this regard, the question ¿What are the main actions taken in terms of sustainability in the shrimp farming sector? To which the director of the state agency CESASIN responded in the interview: We seek to ensure that the food is organic, we comply with the requirements requested by SENASICA, and for international markets we comply with the standards of the Food and Drug Administration (FDA or USFDA).

They are also monitored by CESASIN through the provision of information to ensure that the product is sustainable from the larvae's rearing until it reaches the final consumer. The aim is to maintain a balance in the ecosystem for water quality, and weekly monitoring is carried out. Flora and fauna excluders are used and they are returned to their habitat. 
So it can be seen that there are notions of the importance of the production of organic products, and can be produced according to the demand mainly by international markets such as the United States, however production costs are usually high because the inputs are in dollars and that affects the costbenefit ratio, also, the social and private sector suffer from lack of credit, currently the private sector is supported with its own resources, were the words of the director of CESASIN in the interview.

For their part, [25] agree that production concerned about the environment implies substantial changes in food decisions, which are conditioned by economic and quality factors, unfortunately, the complex integration of all these factors, which sometimes oppose each other, limits the ability of aquaculture producers to adapt their production strategy to cleaner production systems.

\section{Conclusions}

Undoubtedly, the context in which companies develop today has changed, moving towards sustainability, which implies that both their production and marketing systems are increasingly environmentally friendly; likewise, voices demanding greater social responsibility and accountability are growing day by day. It should be noted that innovations in the business model oriented towards sustainable management lead to improved economic, environmental and social performance of the organization.

This has led to an increase in the number of organizations seeking to achieve sustainable management. This translates into a change in the strategic guidelines of the company, orienting the mission, vision and values towards the path of a true sustainability that is part of the backbone of the organization, and that the decisions are oriented towards a more ethical behavior. And aquaculture, more specifically the shrimp farming sector is no exception to this situation.

This sector is of great relevance for the food security of the population and for the national economic development. Furthermore, it has achieved exponential growth in the last thirty years and has great economic, social and environmental relevance. However, despite the economic and social benefits generated by this important activity, it has been criticized for its unsustainable production systems. Therefore, a diagnosis of the practices carried out in this important sector was carried out.

According to the results obtained after the development of the field work and the literature review, it is concluded that there are notions of the importance of the management of factors aimed at sustainability, such as environmental, economic and social. However, there is a bias towards the environmental dimension due to the nature of the activity, since, if there is a good relationship with the environment, this allows the activity to be sustainable. However, despite all the above, there is still a vague ecological awareness in the sector.

Also, companies with an environmental commitment are less likely to exit the industry because there is a positive effect of economic profitability and long-term solvency on survival. All this is due to the positive image that is generated of the organization by the implementation of practices aimed at the care and preservation of the environment, which translates into good relations with the different stakeholders, all this as a result of committing to the development of sustainable management.

In order to compete in international markets, it is essential for this sector to develop strategies and guidelines aimed at achieving sustainable management, which will make it possible to meet the

requirements of international organizations and create economic and non-economic value. It should be noted that there is still much to be done in terms of sustainable management in this sector, since actions aimed at this type of management rarely exceed the existing legal requirements. 


\section{References}

[1] R. N Gálvez,., \& J. G. Salas: La industria camaronícola y la responsabilidad social. Caso Sinaloa. Políticas de gestión y estrategias para fortalecer el desarrollo local de México, 221.

[2] R. Durand, , O. Hawn \& I. Ioannou: Willing and able: A general model of organizational responses to normative pressures. Academy of Management Review, 44(2), (2019) 299-320. https://doi.org/10.5465/amr.2016.0107

[3] E. Raufflet, L. Portales, C. García de la Torre, J. F. Lozano, \& E. Barrera: Responsabilidad, ética y sostenibilidad empresarial. Pearson Educación. (2017).

[4] S. Evans, D. Vladimirova, M. Holgado, K. Van Fossen, M. Yang, , E. A. Silva, \& C. Y. Barlow: Business model innovation for sustainability: Towards a unified perspective for creation of sustainable business models. Business Strategy and the Environment, 26(5), (2017) 597-608. https://doi.org/10.1002/bse.1939

[5] M. Geissdoerfer, D. Vladimirova \& S. Evans: Sustainable business model innovation. A review. Journal of cleaner production, 198, (2018) 401-416. https://doi.org/10.1016/j.jclepro.2018.06.240

[6] J. Y. Yong, M. Y Yusliza, C. J. Jabbour, \& N. H. Ahmad: Exploratory cases on the interplay between green human resource management and advanced green manufacturing in light of the AbilityMotivation-Opportunity theory. Journal of Management Development. 1(39) (2020) 31-49. https://doi.org/10.1108/JMD-12-2018-0355

[7] C. J. Jabbour, Sarkis, J. de Sousa Jabbour, A. B. Renwick, D. W. S. Singh, S. K. Grebinevych, O. \& M. Godinho: Who is in charge? A review and a research agenda on the 'human side'of the circular economy. Journal of cleaner production, 222, (2019) 793-801. https://doi.org/10.1016/j.jclepro.2019.03.038

[8] FAO: El estado mundial de la pesca y la acuicultura. Contribución a la seguridad alimentaria y la nutrición para todos. (2016).

[9] FAO: El estado mundial de la pesca y la acuicultura. Contribución a la seguridad alimentaria y la nutrición para todos. (2018).

[10] CONAPESCA: Produjo México 47 mil 664 toneladas de camarón en la temporada de captura 2019-2020: Agricultura. (2020). https:/www.gob.mx/conapesca/articulos/produjo-mexico-47-mil664-toneladas-de-camaron-en-la-temporada-de-captura-2019-2020-agricultura?idiom=es (accessed february 22, 2021).

[11] CONAPESCA: Produjo México 47 mil 664 toneladas de camarón en la temporada de captura 2019-2020: Agricultura. (2020) https://www.gob.mx/conapesca/articulos/produjo-mexico-47-mil-664toneladas-de-camaron-en-la-temporada-de-captura-2019-2020-agricultura?idiom=es (accessed february 25,2021 ).

[12] A. Plascencia y M. Almada: La acuicultura y su impacto al medio ambiente. Estudios Sociales. Revista de alimentación contemporánea y desarrollo regional, (2), 221-232 (2012).

[13] T. Ytrestøyl, T.S Aas \& T. Åsgård: Utilisation of feed resources in production of Atlantic salmon (Salmo salar) in Norway. Aquaculture 448, (2015). 365-374. https://doi. org/10.1016/j.aquaculture.2015.06.023

[14] M. Salas, A. Durazo \& J. Enrique: La acuicultura y su impacto en la zona costera del Golfo de California. Biotecnia, 18(3), (2016) 37-46. https://doi.org/10.18633/biotecnia.v18i3.334

[15] T. C. Osmundsen, V. S. Amundsen, K. A Alexander, , F Asche, J. Bailey, B. Finstad \& H. Salgado: The operationalisation of sustainability: Sustainable aquaculture production as defined by certification schemes. Global Environmental Change, 60, $102025 \quad$ (2020). 


\section{https://doi.org/10.1016/j.gloenvcha.2019.102025}

[16] Á. Borja: Los impactos ambientales de la acuicultura y la sostenibilidad de esta actividad. Boletín. Instituto Español de Oceanografia, 18(1-4), 41-49 (2011).

[17] Naciones Unidas: Objetivos de Desarrollo Sostenible. (2017) :https://www.un.org/sustainabledevelopment/es/sustainable-consumption-production/__ (accessed february 01, 2021).

[18] L. Martínez-Córdova, M. Martínez-Porchas \& E. Cortés-Jacinto: Mexican and world shrimp aquaculture: sustainable activity or contaminant industry. Revista internacional de contaminación ambiental, 25(3), 181-196 (2009).

[19] FAO: El estado mundial de la pesca y la acuicultura. Contribución a la seguridad alimentaria y la nutrición para todos. (2014).

[20] M. O. Solís: La Acuicultura y sus efectos en el medio ambiente. Espacio I+ D, Innovación mas desarrollo, 2(3) (2013). 10.31644/IMASD.3.2013.a04

[21] J. Vince, \& M. Haward: Certification Schemes and Third Party Accreditation: Hybrid Governance in the Marine and Aquaculture Sector. In 3rd International Conference on Public Policy (ICPP3) (2017).

[22] K. A. Alexander, V. S. Amundsen.\& T. C. Osmundsen: 'Social stuff'and all that jazz: Understanding the residual category of social sustainability. Environmental Science \& Policy, 112, (2020) 61-68. https://doi.org/10.1016/j.envsci.2020.06.003

[23] W.Valenti, J. Kimpara, B Preto, \& P. Moraes-Valenti: Indicators of sustainability to assess aquaculture systems. Ecological indicators, 88, 402-413 (2018).

[24] A. Plascencia y M. Almada: La acuicultura y su impacto al medio ambiente. Estudios Sociales. Revista de alimentación contemporánea y desarrollo regional, (2), 221-232 (2012).

[25] M. Luna, I. Llorente \& Á. Cobo: Integration of environmental sustainability and product quality criteria in the decision-making process for feeding strategies in seabream aquaculture

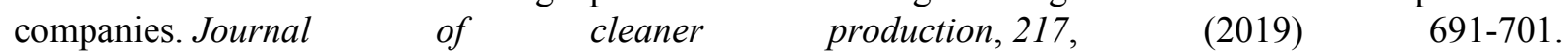
https://doi.org/10.1016/i.jclepro.2019.01.248

[26] Freeman, R. E. (1984). Strategic management: A stakeholder approach. Pitman Publishing Inc, Boston.

[27] M. V. Martín, R. Reinhardt \& S. Gurtner: The dilemma of downstream market stakeholder involvement in NPD: Untangling the effects of involvement and capabilities on performance. Journal of Business Research, 124, (2021) 136-151. https://doi.org/10.1016/j.jbusres.2020.11.040

[28] L. M. Sharpe, M. C. Harwell \& C. A. Jackson: Integrated stakeholder prioritization criteria for environmental management. Journal of Environmental Management, (282) (2021) 111719. https://doi.org/10.1016/j.jenvman.2020.111719

[29] Y. T. Salamanca, A. D. Cortina, \& D. García Ríos: Modelo de gestión organizacional basado en el logro de objetivos. Suma de negocios, 5(spe11), (2014) 70-77. DOI: 10.1016/S2215-910X(14)700217

[30] L. S. Purnell \& R. E. Freeman: Stakeholder theory, fact/value dichotomy, and the normative core: How Wall Street stops the ethics conversation. Journal of Business Ethics, 109(1), 109-116 (2012).

[31] P. F. Tamayo-García: Metodología para la integración de los sistemas de gestión organizacional. Ciencias Holguín, 21(3), 1-18 (2015).

[32] ONU:Nuestro futuro común. Madrid: Alianza. (1987). 
[33] P. Kent: Gestión y evaluación de la sustentabilidad organizacional. Ciencias Administrativas. Num. 15, (2020) 1-11. https://doi.org/10.24215/23143738e058

[34] J. Carro-Suárez, S. Sarmiento-Paredes \& G. Rosano-Ortega: La cultura organizacional y su influencia en la sustentabilidad empresarial. La importancia de la cultura en la sustentabilidad empresarial. Estudios gerenciales, 33(145),

(2017)

352-365.

https://doi.org/10.1016/j.estger.2017.11.006

[35] J. E. Andrade: La gestión comercial y su influencia en el crecimiento de las PYMES hoteleras de Manabí. ECA Sinergia, 8(2), (2017) 54-68.

[36] M. Clarke-Bloomfield, Y. Cisneros-Arias \& Y. Paneca-González: Gestión Comercial: diagnóstico del atractivo y rentabilidad del punto de ventas. Ciencias Holguín, 24(4), (2018)11-25.

[37] R. Yin: Case study research: design and methods, 3th ed., London: Sage Publications. (2003).

[38] CESASIN: Programa de sanidad en crustáceos. (2020). http://cesasin.mx/programacrustaceos/ (accessed february 01, 2021).

[39] R. Hernández, C. Fernández \& M. Baptista metodología de la investigación. 5 ta edición. 40. Ministerio de educación. Escala de la calidad educativa, disponible en: escale. minedu. gob. pe. (2010).

[40] R. Hernández-Sampieri \& C. Torres: Metodología de la investigación (Vol. 4). México eD. F DF: McGraw-Hill Interamericana. (2018).

[41] M. Porter y M. Kramer: Creando valor compartido. Harvard Business Review, 0 , 0 (2011).

[42] P. Kotler \& N. Lee: Corporate Social Resposability. New Jersey: John Wiley \& Sons, Inc. (2011).

[43] E. C. Lagares, F. G. Ordaz \& J. J. del Hoyo: Innovation, environmental commitment, internationalization and sustainability: A survival analysis of Spanish marine aquaculture firms. Ocean \& Coastal Management, 151, (2018) 61-68. https://doi.org/10.1016/j.ocecoaman.2017.10.024

[44] A. Rodríguez: Gestión de Stakeholders: Gestión de grupos de interés. Revista Escuela de Administración de Negocios, (75), (2013) 208-210.

[45] J. Tirado: Relaciones entre organizaciones y stakeholders: necesidad de una interacción mutua entre los diversos grupos de interés. INNOVAR. Revista de Ciencias Administrativas y Sociales, 17(30), (2007) 153-158.

[46] P. B. Bridson, J. M. Stoner, M. H. Fransen, \& J. Ireland: The aquaculture sustainability continuum-Defining an environmental performance framework. Environmental and Sustainability Indicators, 8, 100050 (2020). https://doi.org/10.1016/j.indic.2020.100050 